\title{
SISTEM PENDETEKSIAN KESERASIAN WARNA KULIT DAN BUSANA SECARA OTOMATIS UNTUK JENIS KELAMIN PEREMPUAN BERBASIS IMAGE PROCESSING
}

\author{
Meza Silvana* dan Rahmadi Kurnia** \\ **Mahasiswa S2 Teknik Elektro Universitas Andalas \\ **Staff Pengajar Teknik Elektro Universitas Andalas
}

\begin{abstract}
Abstrak - Keserasian dalam berpakaian menjadi kebutuhan yang tidak bisa dihindari oleh setiap orang, karena ketepatan dalam memilih warna pakaian akan sangat menunjang penampilan seseorang wanita. Sejauh ini penelitian yang telah dilakukan hanya membahas tentang pengelompokan jenis kulit saja ataupun busana saja, dan keserasian warna pakaian juga dilakukan dengan perkiraan manual yang sifatnya relatif. Oleh karena itu, penelitian ini dirancang untuk membuat prioritas warna busana untuk masing-masing jenis warna kulit dengan memperhitungkan fleksibilitas warna kulit dengan warna busana secara otomatis. Sistem akan menentukan prioritas warna busana yang tepat untuk jenis kulit tertentu berdasarkan kombinasi dari beberapa warna pakaian. Proses pengujian dilakukan terhadap masing-masing warna busana untuk melihat seberapa jauh tingkat kesesuaian masing-masing warna busana tersebut terhadap warna kulit. Dari hasil penelitian didapatkan 6 (enam) warna terpilih keserasiannya dengan warna kulit, dan grafik tingkat kecocokan warna pada pengujian sistem telah mendekati hasil grafik data sampel pada database sistem.
\end{abstract}

Kata Kunci : Warna kulit, Keserasian dan Busana

\begin{abstract}
Compatibility of the clothes become a necessity that can not be avoided by everyone, because accuracy in choosing the color of the clothes will be very supportive of woman's appearance. So far, the research has been done only discuss about skin type or the grouping of clothing only, and compatibility of clothing color is also done manually estimates that are relative. Therefore, this study was designed to make a priority fashion color for each type of skin color automatically based on skin color flexibility. The system will determine the priority of the right clothing colors for certain skin types based on a combination of several colors clothes. The testing process is done for each color of clothing to see how far each level according to the fashion color of the skin color. From the results, six (6) elected fashion color with skin color, and the color matching chart rate on the test results chart system has approached the sample data in the database system.
\end{abstract}

Keywords: Skin color, Compatibility and Cloth

\section{PENDAHULUAN}

Warna merupakan sesuatu yang bersifat pribadi. Bagi sebagian orang, apalagi perempuan, pemilihan warna bisa menjadi masalah sensitif. Untuk itu, dianjurkan untuk memilih warna busana yang tepat. Sebaik apapun model busana yang digunakan jika warna yang digunakan tidak serasi atau tidak sesuai dengan warna kulit akan terlihat janggal atau aneh. [13]. Kesalahan dalam memilih warna busana dapat menimbulkan beberapa hal antara lain kulit terlihat kusam dan dekil atau membuat warna gigi menjadi terlihat lebih kuning. Sedangkan pemilihan warna busana yang tepat bisa membuat kulit menjadi lebih cemerlang dan akan membuat si pemakai merasa lebih nyaman.

Mempelajari warna busana yang cocok akan membuat ruang kreativitas untuk membuat variasi busana semakin terbuka luas. Selama ini untuk menentukan serasi atau tidaknya kombinasi busana yang digunakan dengan warna kulit seseorang sering menggunakan aspek dugaan, kira-kira atau kepatutan yang sifatnya masih relatif. Untuk itu diperlukan suatu metode tertentu dalam menentukan keserasian kombinasi dan variasi 
warna busana yang digunakan secara akurat dan bersifat universal. Teknologi ini disesuaikan dengan karakteristik dan warna kulit tubuh manusia yang unik. Karakteristik warna kulit ini dapat berupa kulit wajah, leher, tangan dan kaki. Warna yang terkandung pada kulit manusia memiliki karakteristik yang sangat relevan dengan warna busana, karena perbedaan warna kulit tiap jenis kulit akan memiliki tingkat kecocokan yang berbeda terhadap variasi warna busana. Dengan menentukan warna kulit manusia berdasarkan beberapa parameter diharapkan dapat diupayakan membuat sistem yang dapat menentukan warna busana secara otomatis.

Penelitian-penelitian tentang deteksi kulit atau busana/fashion secara terpisah telah banyak dilakukan, diantaranya penelitian yang dilakukan Murinto, dkk dalam papernya yang berjudul deteksi jenis warna kulit wajah untuk klarifikasi ras manusia menggunakan transformasi warna [1] yang meneliti citra warna kulit wajah dan menggolongkannya ke dalam kelompok ras. Rudra P K poudel,dkk [2] dalam penelitiannya membahas pendeteksian kulit melalui metode region based. Bingsen Zhang [5] membahas tentang keserasian warna pada tekstil dengan metoda least square fitting. Chung M Tsai dan Zong MuYeh [10] tentang pendeteksian warna kulit menggunakan fuzzy logic. Yong $\mathrm{Yu}$ Tsan, dkk [11] membahas tentang membuat sistem cerdas menggunakan logika fuzzy dan ANN dalam mendesain busana yang efisien dan efektif. Dan $\mathrm{Li}$ Chuan Won,dkk [12] tentang otomatisasi produksi fashion dalam perusahaan garmen dengan menggunakan fuzzy logic.

Berdasarkan penelitian-penelitian tersebut belum ada yang mengembangkan sistem pendeteksian kesesuaian warna kulit dengan warna busana secara otomatis. Oleh karena itu penulis mencoba membuat suatu sistem untuk menentukan prioritas warna busana yang tepat untuk jenis kulit tertentu berdasarkan kombinasi dari beberapa warna busana yang divariasikan. Untuk deteksi warna kulit menggunakan distribusi Gaussian dan penyesuaian warna busana menggunakan metoda fuzzy logic. Metode logika fuzzy ini dinilai cocok, karena kemampuan adaptif dari logika fuzzy untuk menyesuaikan dengan nilai yang tidak tetap. Penelitian ini dirancang untuk membuat prioritas warna busana untuk masingmasing jenis warna kulit dengan memperhitungkan fleksibilitas warna kulit dengan warna busana.

\section{KAJIAN LITERATUR}

\section{Pengantar Ruang warna}

Ruang warna merupakan cara standar untuk menspesifikasikan suatu warna tertentu. Ada beberapa ruang warna yang telah diketahui umum diantaranya adalah $\mathrm{RGB}, \mathrm{YcbCr}$ dan HIS.

\section{$1.1 \quad \mathrm{RGB}$}

Warna RGB adalah model warna yang bertujuan sebagai penginderaan dan presentasi gambar dalam tampilan visual pada peralatan elektronik seperti komputer, televisi dan fotografi. Komponen $\mathrm{R}=\operatorname{Red}$ (merah) $\mathrm{G}=$ Green (hijau) dan $\mathrm{B}=$ Blue (biru) pada RGB adalah warna dasar untuk menentukan intensitas cahaya untuk mencerahkan warna latar belakang yang gelap (hitam).

\section{$1.2 \mathrm{YCbCr}$}

YCbCr merupakan suatu cara penyandian informasi RGB[8]. Pada ruang warna $\mathrm{YcbCr}$, komponen $\mathrm{Y}$ merupakan komponen luminance (kecerahan) sedangkan komponen $\mathrm{Cb}$ dan $\mathrm{Cr}$ disebut juga dengan krominance. $\mathrm{Cb}$ adalah komponen biru dan $\mathrm{Cr}$ merupakan komponen merah yang tidak tergantung pada luminance. Untuk mengkonversi citra RGB ke $\mathrm{YCbCr}$ dapat melakukan langkah-langkah seperti persamaan berikut ini [10]:

$$
\left[\begin{array}{c}
Y \\
C b \\
C r
\end{array}\right]=\left[\begin{array}{c}
16 \\
128 \\
128
\end{array}\right]+\left[\begin{array}{ccc}
64.481 & -37.757 & 112 \\
128,553 & -74.203 & -93.786 \\
24.996 & 112 & -18.214
\end{array}\right]\left[\begin{array}{l}
R \\
G \\
B
\end{array}\right]
$$

\subsection{HIS}

HIS merupakan singkatan dari Hue $(\mathrm{H})$ dilambangkan dengan $\theta$, Intensity (I) dan saturation (S). Dalam ruang warna HIS, Hue merupakan jenis/macam warna, saturasi adalah tingkat kepekatan warna dan intensitas adalah gelap terangnya warna. Untuk mengkonversi 
citra RGB ke YCbCr dapat melakukan langkahlangkah seperti persamaan berikut ini[11]:

$$
\begin{aligned}
& \theta=\cos ^{-1}\left\{\frac{\frac{1}{2}[(R-G)+(R-B)]}{\left[(R-G)^{2}+(R-B)(G-B)\right]^{1 / 2}}\right\} \\
& I=1-\frac{3}{(R+G+B)} \\
& S=1-\frac{3}{(R+G+B)}[\min (R, G, B)]
\end{aligned}
$$

\section{Warna kulit (Skin Color)}

Kulit dapat digunakan sebagai sumber informasi untuk proses pendeteksian karena kulit merupakan salah satu ciri khas dari identifikasi manusia. Dalam pendeteksian citra, warna kulit memiliki sensitivitas yang tinggi terhadap perubahan cahaya. Pengubahan citra kulit dari RGB ke ruang $\mathrm{YcbCr}$ sangat sesuai untuk mendeteksi warna kulit karena pengaruh luminance dapat dihilangkan selama pemrosesan citra[1].

Secara umum kulit manusia dapat dikelompokkan dalam 3 ras utama, yaitu kulit hitam kecoklatan/gelap (negroid), kulit putih kemerahan (kaukasoid) dan kuning kecoklatan/berwarna (mongoloid). Nilai sebaran warna kulit ini dapat dilihat dalam histogram warna kulit pada gambar 1 berikut ini[1]:

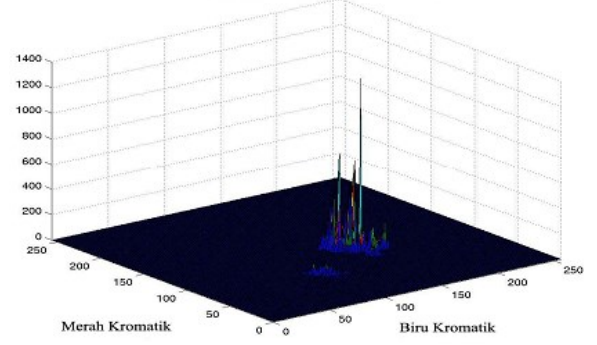

Gambar 1: Penyebaran warna kulit.

\section{Keserasian kombinasi warna pakaian}

Keserasian warna kulit dan warna busana menjadi tolok ukur/parameter dalam menentukan keserasian penampilan seseorang. Contoh kombinasi beberapa warna pakaian dapat dilihat pada gambar2 berikut ini[13]:

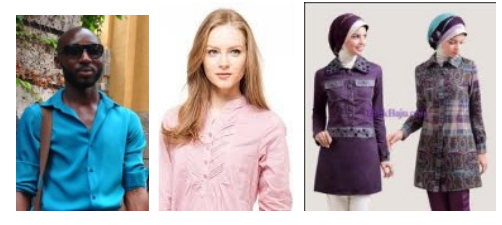

Gambar 2: Beberapa contoh kombinasi warna pakaian.

\section{Logika Fuzzy}

Logika fuzzy dikembangkan oleh Lofti Zadeh pada tahun 1965. Logika fuzzy mempunyai nilai yang kontinu, yang dapat dinyatakan dalam derajat dari suatu keanggotaan. Fungsi keanggotaan yang digunakan pada penelitian ini adalah fungsi keanggotaan kurva segitiga.

Persamaan yang yang digunakan pada fungsi keanggotaan ini dapat dilihat pada persamaan 5 berikut ini[7]:

$$
f(x, a, b, c)=\left\{\begin{array}{cc}
0 & x<a \\
\frac{x-a}{b-a} & a \leq x \leq b \\
\frac{c-x}{c-b} & b \leq x \leq c \\
0 & x>c
\end{array}\right.
$$

Fungsi keanggotaan ini dapat digambarkan pada gambar 3 di bawah ini:

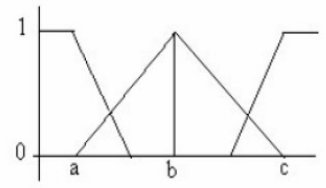

Gambar 3: fungsi keanggotaan kurva segitiga dengan beberapa fungsi $\mathrm{f}(\mathrm{x})$.

\section{METODOLOGI PENELITIAN}

Penelitian ini terdiri dari dua tahap yaitu tahap pertama, mengelompokkan jenis kulit dan tahap kedua, menentukan kesesuaian variasi warna kulit dengan busana. Proses pengelompokan pada kedua tahap ini dapat digambarkan pada blok diagram berikut ini: 


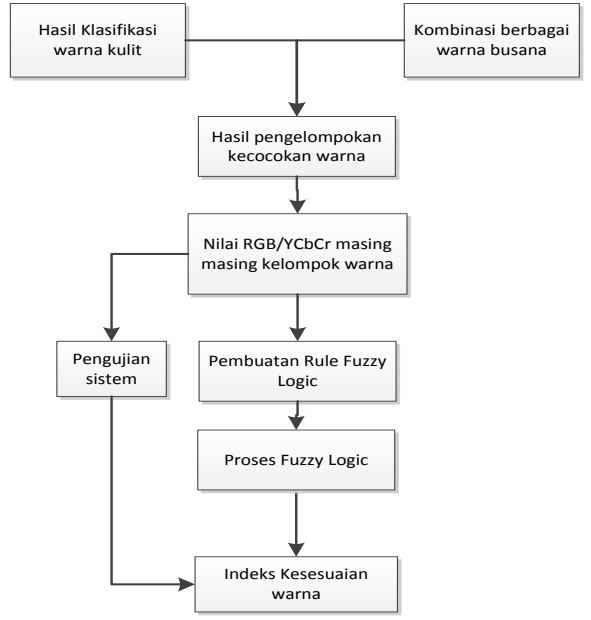

Gambar 4: Blok diagram penentuan tingkat keserasian pakaian dan warna kulit

Kombinasi jenis warna kulit manusia dengan berbagai warna busana (dalam penelitian ini ada 30 warna tekstil) ditentukan pengelompokan kekeserasiannya dari responden. Kemudian dari hasil pengelompukan ini, ditentukan nilai range $\mathrm{YCbCr}$ (untuk warna kulit) dan nilai HIS (untuk warna busana) masing-masing kelompok warna tersebut. Setelah itu dibuat rule fuzzy masingmasing kelompok warna dengan kombinasi beberapa jenis warna kulit. Kemudian dilakukan proses logika fuzzy dengan menentukan membership function estimation dan membuat rule yang tepat untuk sistem ini. Dari hasil proses tersebut dapat ditentukan indeks kesesuaian antara warna kulit dan warna busana. Proses pengujian dilakukan terhadap masing-masing warna busana untuk menguji seberapa jauh tingkat kesesuaian masingmasing warna busana tersebut terhadap warna kulit.

\section{HASIL DAN PEMBAHASAN}

\subsection{Data}

\subsubsection{Rentang Warna Kulit}

Hasil awal penelitian didapatkan dengan melakukan pengambilan nilai jenis Sampel warna kulit yang terdiri dari 3 jenis warna kulit (kulit putih, kulit berwarna dan kulit gelap). Dari sampel ini didapatkan range warna kulit dalam ruang RGB. Kemudian dilakukan konversi ke dalam bentuk YcbCr, untuk memudahkan pengelompokan jenis kulit. Hasil nilai YcbCr ini, dapat dilihat pada tabel 1 berikut:

Tabel 1: Rentang warna Kulit dalam YcbCr.

\begin{tabular}{|c|c|c|c|}
\hline Jenis kulit & Y & Cb & Cr \\
\hline kulit putih & $180-216$ & $197-250$ & $189-200$ \\
\hline $\begin{array}{c}\text { kulit } \\
\text { berwarna }\end{array}$ & $134-186$ & $160-203$ & $155-192$ \\
\hline kulit gelap & $80-140$ & $100-166$ & $100-165$ \\
\hline
\end{tabular}

\subsubsection{Hasil kuisioner keserasian warna Rentang Keserasian warna}

Sampel warna tekstil terdiri dari 30 sampel warna tekstil yang biasa digunakan untuk warna pakaian. Kemudian 30 warna ini direduksi dengan mengambil 3 nilai warna tertinggi pada masing-masing sampel kulit tersebut. Pereduksian warna ini dilakukan dengan memberikan kuisioner kepada 30(tiga puluh) orang terpilih, dengan memberi nilai pada rentang nilai 10 (dimana nilai 1 berati sangat tidak serasi dan nilai 10 berarti sangat serasi). Responden yang dipilih memiliki latar belakang yang beragam untuk menghindari kesamaan persepsi penilaian. Responden juga dipilih setelah diketahui kemampuannya dalam menetapkan warna yang serasi. Pada penelitian ini responden diutamakan berasal dari Sumatera Barat, sehingga memudahkan bagi penulis untuk mengetahui kemampuan responden dalam menetukan keserasian warna).Pada penelitian ini warna tekstil tereduksi menjadi 6 warna (merah, hitam, hijau, biru muda, putih dan abu-abu muda).

Tingkat keserasian warna kulit dengan warna tekstil oleh responden dapat dilihat pada gambar 4.a s/d gambar 4.f berikut:

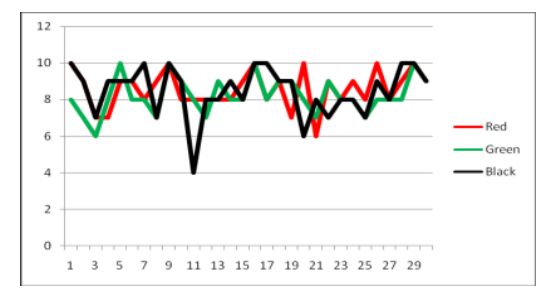

Gambar 4.a: Grafik hasil kuisioner keserasian warna kulit Putih 


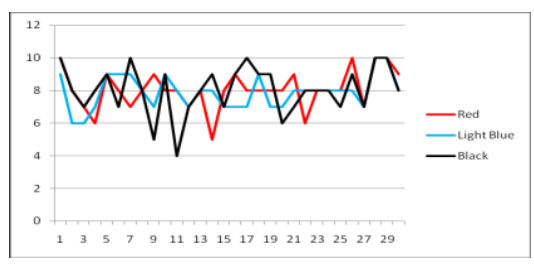

Gambar 4.b: Grafik hasil kuisioner keserasian warna untuk kulit berwarna.

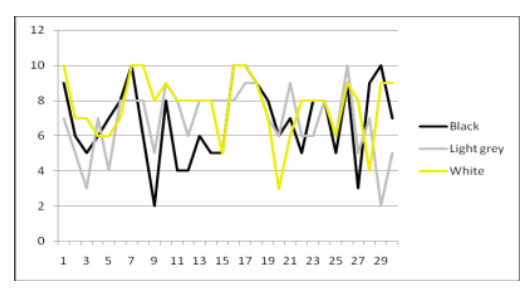

Gambar 4.c: Grafik hasil kuisioner keserasian warna untuk k geulitlap

\subsection{Hasil dan analisa sistem}

\subsubsection{Pengelompokan Keserasian warna}

Pengelompokan keserasian warna kulit dengan warna tekstil dalam ruang warna HSI.dapat dilihat pada Grafik 5(a) s/d Grafik $5(c)$.

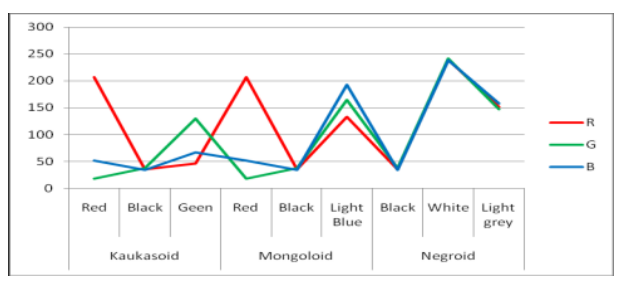

Gambar 5(a): pengelompokan keserasian warna kulit dengan warna tekstil dalam ruang warna RGB

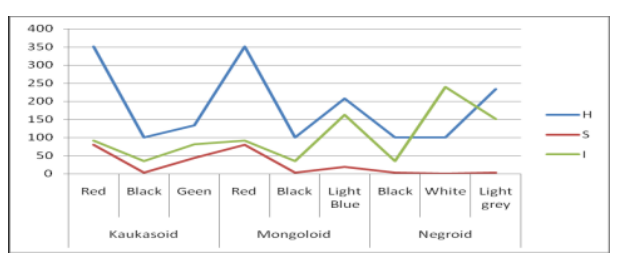

Gambar 5(b): pengelompokan keserasian warna kulit dengan warna tekstil dalam ruang warna HSI

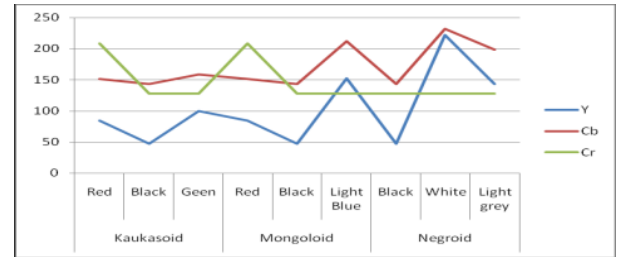

Gambar 5(c): pengelompokan keserasian warna kulit dengan warna tekstil dalam ruang warna YCbCr.

Dari ketiga grafik di atas didapatkan bahwa keteraturan nilai antara hasil pengelompokan warna pada menurut jenis warna kulit adalah pada ruang warna HSI, sedangkan pada ruang warna lain nilainya tidak teratur/tumpang tindih. Sehingga pada penelitian ini, warna tekstil diubah ke dalam bentuk HSI. Selanjutnya warna kulit dengan kelompok warna tekstil yang telah dikelompokkan dari responden ini dimatchingkan dengan metode logika Fuzzy.

\subsection{Membership function logika fuzzy}

Rentang nilai pada ketiga jeni warna kulit dan enam warna tekstil yang terpilih akan menjadi input pada rule fuzzy. Contoh salah satu Membership function logika fuzzy diperlihatkan pada Gambar 6 dan gambar 7 dengan variabel fungsi untuk input dan output menggunakan rule based system fuzzy mamdani.

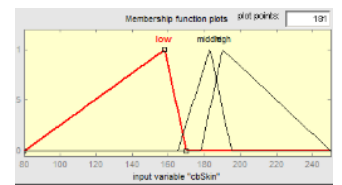

(a)

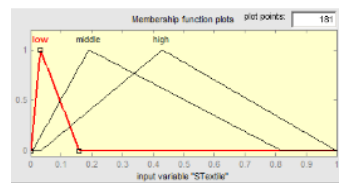

(b)
Gambar 6: Membership function input logika fuzzy, (a) dalam fungsi $\mathrm{Cb}$, (b) dalam fungsi Saturasi.

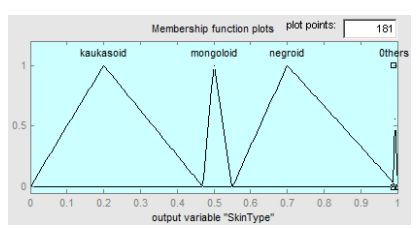

Gambar 7: Membership function output logika fuzzy, dalam 3 range jenis kulit. 
Dari pengujian sistem, nilai output didapatkan untuk kulit putih berada pada range output $0 \mathrm{~s} / \mathrm{d}<0.5$, kulit berwarna $0.5 \mathrm{~s} / \mathrm{d} 0.7$ dan kulit gelap $>0,7$. Berdasarkan input dan output tersebut, pixel kulit dengan $\mathrm{cb}=167$ dan nilai saturasi warna tekstil $=0.5$ memberikan nilai output $=0.752$, nilai ini memberi arti bahwa kulit dengan $\mathrm{Cb} \pm 160$ dan warna tekstil pada saturasi $=0,5$ berada pada rentang keserasian warna pada kulit gelap (negroid). Rule test sistem tersebut dapat dilihat pada gambar 6 berikut:

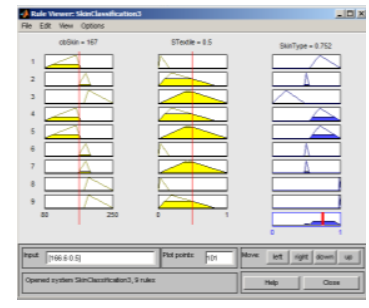

Gambar 9 : Rule test sistem dengan logika fuzzy

\subsection{Output sistem}

Nilai output (Indeks Kesesuaian) keserasian warna kulit terhadap warna tekstil pada sistem dapat dilihat pada grafik pada gambar 10.

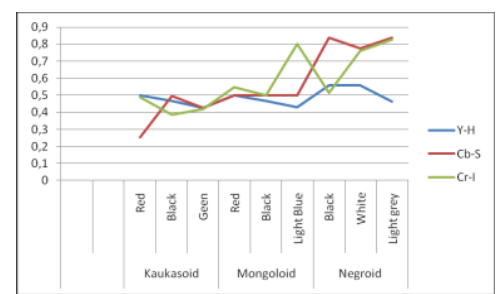

Gambar 10 : Indeks Kesesuaian warna kulit terhadap warna tekstil

Dari grafik dapat dilihat bahwa sistem paling stabil berada pada kombinasi $\mathrm{Cb}-\mathrm{S}$, yang artinya $\mathrm{Cb}$ pada warna kulit dan saturasi pada warna tekstil memberikan nilai output terbaik dan paling stabil, sedangkan $\mathrm{Cr}$ pada warna kulit dan I memberikan hasil yang buruk pada sistem kesesuaian warna. Hal ini disebabkan karena rentang nilai $\mathrm{Cr}$ berada pada nilai yang tidak teratur untuk seluruh warna kulit, sedangkan nilai I pada warna tekstil didapatkan berada pada nilai yang nyaris sama sehingga sistem sulit untuk menentukan pengelompokan warna ke jenis kulit tertentu.

\subsection{Pengujian sistem}

Pengujian sistem dilakukan pada (12 warna kulit) yang berbeda dari sampel. Hasil dari pengujian ini dapat di lihat pada gambar 12 berikut:

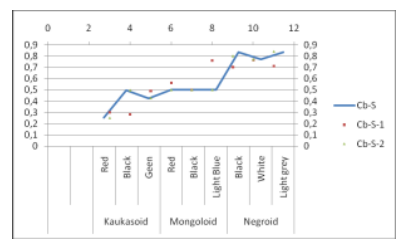

Gambar 12: Hasil pengujian kesesuaian warna kulit dengan warna busana

Dari hasil pengujian terlihat bahwa sistem sudah berjalan sesuai dengan rule fuzzy yang ditetapkan. Hal ini dapat dilihat dari sebagian besar nilai output yang berada dalam rentang output yang ditetapkan. Hanya beberapa output berada di luar rentang yang ditetapkan.

\section{KESIMPULAN}

Pengelompokan range jenis kulit sangat mempengaruhi keserasian warna pakaian, karena kesalahan dalam menetapakan range jenis warna kulit dapat menyebabkan kesalahan sistem dalam mengelompokkan warna pakaian, dimana rentang output akan berada di luar jangkauan output yang ditetapkan. Sistem paling baik berada pada kombinasi $\mathrm{Cb}-\mathrm{S}$, yang artinya $\mathrm{Cb}$ pada warna kulit dan saturasi pada warna tekstil memberikan nilai output terbaik dan paling stabil, sedangkan $\mathrm{Cr}$ pada warna kulit dan I memberikan hasil yang buruk pada sistem kesesuaian warna. Penentuan keserasian warna kulit dengan warna busana pada sistem sudah sesuai dengan rule fuzzy yang ditetapkan

\section{DAFTAR PUSTAKA}

[1] Murinto, dkk., "Deteksi Jenis Warna Kulit Wajah Untuk Klasifikasi Ras Manusia Menggunakan Transformasi 
Warna”. Program Studi Teknik Informatika. Universitas Ahmad Dahlan. Yogyakarta.

[2] Rudra P.K Poudel et al., "Region Based Skin Color Detection," Proceeding International Journal Conference on Computer Vision, Imaging and Computer Graphics Theory and Applications, 2012.

[3] B Zhang, "Research on Numerical Analysis for Color Matching in Textile Dyeing Based on Least Square Fitting," IEEE International Conference on Intelligence and Security Informatics (ISI),2011.

[4] YongY.T. et al., "A New and Efficient Intelligent Collaboration Scheme for Fashion Design," IEEE Transactions on System, MAN and Cybernetics-Part A: System and Human, Vol. 41, No.3, 2011.

[5] Y Yong, et al. "A New and efficient Intelligent Collaboration Sheme for Fashion Design". IEEE Transactions on System, MAN and Cybernetics-Part A: System and Human, Vol. 41, No.3, 2011.

[6] L C Wang, et al. "Formalization of Fashion Sensory Data Based onFuzzy Set Theory". Fourth International Conference on Natural Camputation.

[7] T. Sutoyo, dkk., "Kecerdasan Buatan," Andi ,Yogyakarta, 2011.

[8] M S Iraji, A Tosinia. “ Skin Color segmentation in YCbCr Color Space with Adaptive Fuzzy Neural Network (ANFIS)". I J Image, graphics and signal Processing. Vol.4 Hal 35-41. 2012

[9] Phung SL, et al. "Skin Segmentation Using Color Pixel Classification : Analysis and Comparison. 2005

[10] R. Munir., "Pengolahan Citra Digital dengan Pendekatan Algoritmik," Informatika, Bandung, 2004.

[11] E. Prasetyo, " Pengolahan Citra Digital dan Aplikasinya Menggunakan MATLAB". Andi Yogyakarta, 2011.

[12] A.K. Jain, "Fundamental of Digital Image Processing. University of California. Prentice Hall Int'1. 1989.

[13] http://www.yes24.co.id/NineView/ 3524/tips-memilih-baju-fashion-wanitasesuai-warna-kulit.html.

\section{Biodata Penulis}

Meza Silvana, Lahir di Jakarta pada tahun 1981. Menerima gelar sarjana dari Fakultas teknik Universitas Andalas pada tahun 2006. Sekarang tengah menempuh pendidikan jenjang Magister Teknik elektro Universitas andalas Padang 